\title{
LUT
}

University

\section{Institutional environment and network competence in successful SME internationalisation}

Torkkeli Lasse, Kuivalainen Olli, Saarenketo Sami, Puumalainen Kaisu

This is a Author's accepted manuscript (AAM) version of a publication

published by Emerald Publishing Limited

in International Marketing Review

DOI: 10.1108/IMR-03-2017-0057

Copyright of the original publication: (c) Emerald Publishing Limited 2018

Please cite the publication as follows:

Lasse Torkkeli, Olli Kuivalainen, Sami Saarenketo, Kaisu Puumalainen, (2018) "Institutional environment and network competence in successful SME internationalisation", International Marketing Review, https://doi.org/10.1108/IMR-03-2017-0057

This is a parallel published version of an original publication. This version can differ from the original published article. 
This is an Author's Original Manuscript (AAM) of an article published by Emerald in International Marketing Review. Please cite the final published article:

Lasse Torkkeli, Olli Kuivalainen, Sami Saarenketo, Kaisu Puumalainen, (2018) "Institutional environment and network competence in successful SME

internationalisation", International Marketing Review, https://doi.org/10.1108/IMR03-2017-0057

Lasse Torkkeli*, Olli Kuivalainen*+, Sami Saarenketo* \& Kaisu Puumalainen*

*Lappeenranta University of Technology, School of Business and Management

P.O.Box 20

FI-53851 Lappeenranta

Finland

+ Alliance Manchester Business School, the University of Manchester, Manchester, UK 


\title{
Institutional Environment and Network Competence in Successful SME
}

\section{Internationalisation}

\begin{abstract}
Purpose: This study examines the impact of institutional environment on the international performance of small- and medium-sized enterprises (SMEs) and how this relationship is influenced by network competence.
\end{abstract}

Design/methodology/approach: This study uses a quantitative approach. In total, 119 internationally operating Finnish SMEs from five industry sectors are sampled via a crosssectional survey. Data are analysed through regression modelling.

Findings: The international performance of SMEs is influenced directly and indirectly by institutional drivers. The results show that network competence mediates the positive relationship between institutional drivers and international performance.

Research limitations/implications: Network capability development can help SMEs leverage more or less favourable institutional environments for successful internationalisation. Perceived institutional drivers directly result in higher performance, but the effect can be partially mediated by dynamic capabilities. The limitations of the study include its singlecountry context and the cross-sectional nature of the data.

Practical implications: SMEs should take their home countries' institutional environments into account, but for long-term success, they should develop the ability to manage their business networks. A conducive institutional environment may help develop competence, which in turn can enable more successful internationalisation in terms of scale, scope and satisfaction.

Social implications: Decision-makers may benefit from knowing that, in addition to capabilities, an institutionally conducive environment that drives domestic SMEs toward international markets may be an antecedent of successful internationalisation in the SME sector.

Originality/value: This is one of the few studies to illustrate how network capabilities can mediate the influence of institutional factors on entrepreneurial internationalisation. It combines institutional theory and the dynamic capabilities view to explain successful SME internationalisation.

Keywords: Internationalisation, Networks, Performance, Small- and Medium-sized Enterprises, Competences, Finland 


\section{Introduction}

This study investigates the combined effect of institutional forces and network-related dynamic capabilities on the internationalisation outcomes of small- and medium-sized enterprises (SMEs). There are often discussions in both academia (e.g. Minnitti, 2008) and society regarding how to best promote entrepreneurial activity and growth. However, to take advantage of international growth opportunities, enterprises need to develop innovative international strategies (see Kalinic, Sarasvathy and Forza, 2014), specifically, dynamic capabilities. In addition, marketing capabilities are linked to international entrepreneurship (Knight, 2000) and international diversification strategies (Nath, Nachiappan and Ramathanan, 2010). Therefore, international marketing literature can benefit from more knowledge concerning these capabilities (Morgan, Feng and Whitler, 2018). For SMEs, network capabilities can be beneficial since they facilitate international expansion, especially among smaller companies (Torkkeli, Puumalainen, Saarenketo and Kuivalainen, 2012).

Though both institutional forces and dynamic network capabilities are relevant to the international entrepreneurship and business fields, they have usually been examined separately; the institutional environment has mostly been assessed at the national level and dynamic capabilities have been assessed at the firm or individual level. To bring these streams of literature closer, we aim to answer the focal research question of this study: What is the relationship between the perceived institutional environment and network capabilities in successful internationalisation of SMEs? To justify our research focus, we identified three main gaps in the extant research. 
First, current studies have indicated that the institutional environment can have an impact on entrepreneurial creation (Urbano and Alvarez, 2014), yet a recent literature review on the application of institutional theories in entrepreneurship and international business research concluded that most extant studies have focused on national-level analysis ( $\mathrm{Su}$, Zhai and Karlsson, 2017). As a result, the role of institutional forces at the level of enterprises and industry sectors has remained relatively unaddressed. International entrepreneurship scholars have also noted that the way in which the institutional environment of an enterprise influences internationalisation is a recent topic of interest and a potentially fruitful area for continued research (Jones, Coviello and Tang, 2011; Kiss, Danis and Cavusgil, 2012; Szyliowicz and Galvin, 2010; Veciana and Urbano, 2008). This study responds to this call for research by highlighting the impact of the institutional environment on SME internationalisation at the firm level.

Second, Su et al. (2017) concluded that researchers tend to assume a direct relationship between institutions and entrepreneurial outcomes. However, they and other researchers suggest that this relationship can also be indirect. For instance, Hopp and Stephan (2012) found that the impact of cultural norms on venture creation is mediated by entrepreneurial self-efficacy and motivation. In addition, Stephan and Uhlaner (2010) found that supply- and demand-side variables mediate the relationship between cultural factors and entrepreneurial outcomes, and Zhang, Gao and Cho (2017) found that international entrepreneurial capabilities mediate institutional environment and performance. This study seeks to further clarify the indirect relationships between the institutional environment and international entrepreneurship. 
Third, this study specifically studies the role of the institutional environment in the context of networks and international entrepreneurship. It extends prior studies (Acedo and Casillas, 2007; Danis and Kiss, 2008; Eriksson, Fjelstad and Jonsson, 2017; Narooz and Child, 2017) by also accounting for network-related dynamic capabilities and investigating how the construct of network competence (Ritter, Wilkinson and Johnston, 2002) is related to the institutional environment and international performance of SMEs in a developed market context.

For practitioners, the results of this study also bring added value: For managers of SMEs seeking successful internationalization in scale and scope, the results of this study emphasize the need to develop dynamic capabilities in order to make the best use of home-country drivers foreign operation expansion. This study continues with a review of the central literature on the topics mentioned above. Next, the hypothesis development and research methodology are presented. Then, the empirical results and their implications for theory and practice are considered. Last, the limitations of this study are addressed and avenues for future research are suggested.

\section{Theoretical Background}

\section{Institutional Theory and Entrepreneurship}

When discussing the concept of institutional environment (or institutional forces), this study refers to institutional theory, a framework that comprises the social forces that are external to organisations but impact organisational behaviour (Scott, 1991; 1995). (Neo-)institutional theory further suggests that this impact is manifested in the norms and beliefs that shape the reality of an organisation (Hoffman, 1999). However, classical institutionalism, which has 
evolved into neo-institutional theory, offers economic as well as sociological and organisational views on institutions.

The definition of an institution varies depending on the conception of social reality and the research paradigm. The main difference between these definitions is related to how they prioritise institutional elements. Institutions are thus defined as the 'rules of the game in a society or, more formally, $[\ldots]$ the humanly devised constraints that shape human interaction' (North, 1990, p. 3); taken-for-granted assumptions (Meyer and Rowan, 1991); shared interaction sequences (Jepperson, 1991); activities, beliefs and attitudes that have acquired a taken-for-granted or rule-like status in the entrepreneur's environment (Bruton and Ahlstrom, 2003; DiMaggio, 1991) and 'social structures that have attained a high degree of resilience' (Scott, 2001, p. 48).

Scott (1995) offered a structured three-pillar construct for defining institutions and their underlying structures consisting of regulative, normative and cultural-cognitive elements or pillars. Hoffman (1997, p. 36) referred to these as the 'vital ingredients' of any institution, which exist on a continuum 'from the conscious to the unconscious, from the legally enforced to the taken for granted'. The regulative pillar comprises the rules and laws that influence the future behaviour of objects by enforcing rewards or punishments for conformity or nonconformity, respectively. The normative pillar emphasises the values and norms that have prescriptive, evaluative and obligatory meanings. A normative system not only defines 'goals or objectives (e.g., winning the game, making a profit), but also designates appropriate ways to pursue them (e.g., rules specifying how the game is to be played, conceptions of fair business practices)' (Scott, 2001, p. 55). The cognitive or cultural-cognitive pillar constitutes internal interpretation of an external cultural framework in the form of scripts and beliefs. 
These constitutive elements of the institutional environment determine, to a significant extent, the legitimate strategic actions of a firm within a particular country (Dickson and Weaver, 2008; Scott, 2001).

Extant research on institutional environments has shed light on the institutional profiles of different countries. For example, Busenitz, Gomez and Spencer (2000) and Kostova (1997) validated a measure for institutional pillars at the country level in multi-country empirical settings. In so doing, they provided empirical verification that the institutional environment of a given country can be quantifiably measured. Sambharya and Musteen (2014) identified country-level differences in necessity- and opportunity-based entrepreneurship. Additionally, the state itself can be seen as a type of entrepreneur under the guise of institutional entrepreneurship (Nasra and Dacin, 2010).

The research on institutional forces on entrepreneurship has found that the institutional environment of a country can significantly either drive or prevent certain types of entrepreneurial activity. However, overall, this body of research has tended to favour the national macro level over the meso- and micro-levels of analysis (Su et al., 2017). At the corporate (meso-)level, whereas the concepts of legitimacy, isomorphism and mechanisms of institutional pressure are discussed in the domain of international management (Kostova, Roth and Dacin, 2008), international marketing studies are built upon neo-institutional foundations, such as institutional, cultural and psychic distance, and are often linked to international business. Yang, Su and Fam (2012) show that companies need to develop governance strategies to deal with host-country institutions and gain social acceptance and, thus, improved performance. On the other hand, Dow and Larimo (2009) criticise the concept of institutional distance in entry mode research, and the market orientation of foreign 
subsidiaries is linked to legal institutions (Kirca, Bearden and Roth, 2011). Peng (2003) explained how institutional change in transition economies can impact the strategic choices a given company makes. Balabanis, Theodosiu and Katsikeas (2004) note that institutional theory can be used to jointly study marketing activities and the entrepreneurship process.

In entrepreneurship literature, institutional theory and the institutional environment have been studied from different perspectives. As Baumol (1996) argued, entrepreneurial behaviour can depend heavily on the institutional environment (i.e. the 'rules of the game'). Urbano and Alvarez (2014) explained entrepreneurial behaviour using a three-pillar institutional view. Institutional theory 'has proven to be especially helpful to entrepreneurial research' (Bruton, Ahlstrom and Li, 2010, p. 421). The relevance of institutions and the applicability of institutional theory have led research on them to be extended from macro-level country comparisons to the fields of international marketing, international business and entrepreneurship. While marketing and entrepreneurship have tended to remain distinct streams of literature, institutional theory serves as a way to link the two (Webb, Ireland, Hitt, Kistruck and Tihanyi, 2011).

Institutional theory has been applied to the field of international entrepreneurship as well. The regulative, normative and cognitive institutional settings in home and host countries tend to influence the internationalisation decisions of entrepreneurs (Lim, Morse, Mitchell and Seawright, 2010), their chosen entry mode (Brouthers, 2002; Brouthers and Hennart, 2007; Yiu and Makino, 2002) and their chosen target countries. These choices, in turn, may be shaped by the concept of psychic distance (Johanson and Vahlne, 1977), cultural distance (Brouthers and Brouthers, 2001; Shenkar, 2001) or institutional distance (Kostova and Zaheer, 1999; Phillips, Tracey and Karra, 2009). Informal institutions at the country level can 
also impact the extent of international entrepreneurship; Muralidharan and Pathak (2017) linked high levels of self-expression and performance orientation and low levels of social desirability to increased internationalisation within new enterprises. Chen, Saarenketo and Puumalainen (2018) found that the social value orientation of a venture negatively moderates the home country formal institutions-likelihood of internationalization relationship In addition, institutional settings may also determine the speed at which firms establish foreign operations (Gaba, Pan and Ungson, 2002). Thus, there is little doubt that the institutional environment is relevant to entrepreneurs in general and to international entrepreneurship in particular.

\section{Networks and Network Capabilities in International Entrepreneurship}

Business networking has been defined as 'two or more organizations involved in long-term relationships' (Thorelli, 1986, p. 37) through linkages ('nodes') between networked parties ('actors') (Håkansson, 1982; Håkansson and Snehota, 1989). Some original descriptions of internationalisation, especially the network approach (Johanson and Mattsson, 1988) and the revised U-model (Johanson and Vahlne, 2003; 2009), state that internationalisation occurs via learning through networks and is driven by the gradual acquisition of new market knowledge through business relationships between network actors. Some of these actors may reside in foreign markets and thus offer potential avenues through which organisations can learn about foreign markets and subsequently enter and commit to them. Yamin and Kurt (2018) then further emphasized the role that social network theory has in the Uppsala model.

Business networking is considered essential for successful internationalisation among SMEs. In fact, the domain is considered important enough to warrant its own branch in the research ontology of international entrepreneurship (see Jones et al., 2011). The relevance of networks 
to international entrepreneurship has been recognised for a long time in the context of international new ventures (Oviatt and McDougall, 1994). It has also been recognised in SME internationalisation studies that have challenged traditional models of internationalisation (Bell, 1995) and conceptualised new types of international enterprises, such as international new ventures (Oviatt and McDougall, 1994; 2005), born global firms (Rennie, 1993), and micro-multinational firms (Dimitratos, Johnson, Slow and Young, 2003).

Extant empirical studies report such linkages in all types of entrepreneurial internationalising companies. Dimitratos, Amorós, Etchebarne and Felzen (2014) find that networking with domestic and international partners determines the likelihood of a firm becoming micromultinational. Both Aspelund, Madsen and Moen (2007) and Sasi and Arenius (2008) find that networks enable international new ventures to overcome their inherent size constraints and rapidly internationalise. Madsen and Servais (1997) also suggested that hybrid structures such as business networks are important, especially for the internationalisation of born global firms. Additionally, the foreign entry mode decisions of such companies are, to a large extent, dependent on their network ties (Sharma and Blomstermo, 2003).

Regardless of the rapidity of the internationalisation process, SMEs can leverage business network relationships to enter foreign markets. In doing so, business networks, rather than social networks, can influence an SME to change its strategy and mode of entry (Agndal and Chetty, 2007). SMEs' market entry initiatives are likely to originate from opportunities created through business networks (Coviello and Munro, 1995), and embeddedness in business networks helps SMEs to grow internationally (Coviello and Munro, 1997). 
In line with the network approach to internationalisation (Johansson and Mattsson, 1988), business networks may consist of both foreign and domestic organisations, the latter of which are important for SMEs to increase their international competitiveness and gain foreign market knowledge (Holmlund and Kock, 1998; see also Loane and Bell, 2006). Domestic network centrality can also predict international innovation in SMEs (Nyuur, Brecic and Debrah, 2018). Thus, the extant research clearly indicates that the networks in which an SME is active facilitate its resource development, which leads to internationalisation.

It has been argued that leveraging networks is a firm-specific ability and that firms can improve their ability to develop and manage network relationships. When they do, they are said to possess network capability (Mitrega, Forkmann, Ramose and Henneberg, 2012) or network competence (Ritter, 1998; Ritter et al., 2002). These dynamic capabilities (Teece, Pisano and Shuen, 1997; Eisenhardt and Martin, 2000) concern 'the firm's ability to integrate, build, and reconfigure internal and external competences to address rapidly changing environments' (Teece et al., 1997, p. 516), or 'the firm's processes that use resources, specifically the processes to integrate, reconfigure, gain and release resources, to match and even create market change' (Eisenhardt and Martin, 2000, p. 1107)

In this study, the focus is on network competence, as it consists of both competence in dyadic network relationships, termed relationship-specific network competence (RSS), and the ability to develop a business network as a whole, termed cross-relational network competence (CRR) (Ritter et al., 2002). Network competence was originally suggested to have implications for firm internationalisation (Ritter et al., 2002), and it was later confirmed to be linked to internationally operating SMEs' internationalisation propensity and performance (Torkkeli et al., 2012). Moreover, network capabilities contribute to post-entry survival of 
international new ventures (Khan and Lew, 2018). Extant research also suggests that SME internationalisation is, to a large extent, network-driven and that firms' ability to develop and manage their network relationships (i.e. their network competence) is linked to more favourable internalisation outcomes.

There have been attempts to adapt institutional theory to suit the literature on industrial networks (e.g. Melo Brito, 2001). Additionally, evidence that networks and institutions are linked has been provided by scholars such as Shirokova and McDougall-Covin (2012), who suggest that, in the context of Russia, the institutional environment can override the role of networks in facilitating entrepreneurial internationalisation.

However, extant studies examining the institutional environment have tended to concentrate on the macro level. While several international entrepreneurship studies have noted the important influence of the external environment on the internationalisation process (e.g. Chakravarthy 1997; Jones and Coviello, 2005), there is a distinct lack of evidence on 1) how the institutional environment influences the internationalisation outcomes of SMEs, especially those originating from developed markets; 2) how dynamic capabilities influence the impact of the institutional environment on entrepreneurial internationalisation and 3) how the capability to develop network relationships, which is deemed important by international entrepreneurship research, influences this impact. In the next section, hypotheses concerning these research gaps are presented and tested with empirical data about SMEs originating in a developed market, Finland.

\section{Hypothesis Development}


Based on the extant literature and identified research gaps, this study examines the direct and indirect effects that the institutional environment can have on SMEs' international success. The initial assumption concerning the direct relationship is that both institutional drivers and barriers have an effect on the success of SMEs' internationalisation. This assumption is based on extant literature linking institutional environments to entrepreneurial outcomes. For instance, it has been found that favourable institutional environments are conducive to entrepreneurial decisions to establish a new company (Lim et al., 2010) and entrepreneurial activity (Stenholm, Acs and Wuebker, 2013). Further, Stephan and Uhlaner (2010) and Hopp and Stephan (2012) illustrate how an institutional environment can influence entrepreneurial outcomes.

Regarding international entrepreneurship, the initial decision of an SME to pursue an internationalisation strategy can be, to an extent, dependent on their home countries' institutional environments (Volchek, Jantunen and Saarenketo, 2013). Bell and Cooper (2018) further find that several types of institutional knowledge are relevant for internationalizing SMEs. Zhang et al. (2017) found that sub-national institutions impact the international performance of SMEs in China and Korea indirectly through their international entrepreneurial capabilities. Also, Kiss et al. (2012) concluded that the institutional environment of an emerging market can impact entrepreneurial internationalisation, which can happen through institutional interactions (Oyedele and Firat, 2018).

These results might be due to the fact that path dependence in these institutional structures (see D'Arcy, 2009) could be advantageous in the long term, enabling SMEs to develop the knowledge and strategy needed for improved performance both domestically and internationally. DiMaggio (1988) argued that companies with previous experience in 
international markets could create new institutions to further the interests they value, thus improving their international performance. Institutions are typically conservative structures that maintain functions and business operations for long periods of time (Rajagopal, 2000). This suggests that their impact may extend longitudinally, thus affecting the scale and scope of the international operations - or the degree of internationalisation - that firms are able to achieve.

Only a few studies have examined institutions in the international entrepreneurship domain and considered a developed market context, and most of these have investigated specific organisational aspects of institutions. For instance, Eriksson et al. (2017) examined bank relationships in firms' home and host countries, and Narooz and Child (2017) examined how institutional support affects decision makers' networking behaviour in the United Kingdom and in Egypt. Both of these studies suggest that the institutional environment of an SME's home country could have an impact on its behaviour. Thus, it is reasonable to posit that the significant role of favourable (or unfavourable) institutional environment in the entrepreneurial internationalisation outcomes of SMEs could extend from emerging market contexts, which are more commonly examined, to developed markets.

It is proposed in this study that the perceived driving forces in the Finnish institutional environment have a positive impact on SME internationalisation and the perceived institutional barriers have a negative effect. In other words, an institutional environment that is conducive to international operations should have beneficial effects on the international activities of SMEs, enabling these enterprises to widen the scale and scope of their foreign operations while fulfilling the strategic goals of internationalisation and thus enhancing their performance. Thus, the following hypotheses are proposed: 
H1: SMEs that perceive a more favourable institutional environment have better international performance.

H2: SMEs that perceive fewer institutional barriers have better international performance.

In addition to the direct relationship between the institutional environment and SMEs' internationalisation posited in $\mathrm{H} 1$ and $\mathrm{H} 2$, it is hypothesised that there is an indirect relationship mediated by network capabilities. Based on the extant literature, one can presume that network capabilities have a direct positive impact on internationalisation outcomes in SMEs. In international entrepreneurship literature, dynamic capabilities in general and networking capability in particular have been recognised as important to small technologyintensive firms known as born globals (e.g. Mort and Weerawardean, 2006; Weerawardena, Mort, Liesch and Knight, 2007). Specifically, network competence (Ritter et al., 2002) can have a direct positive influence on the internationalisation propensity and international performance of SMEs (Torkkeli et al., 2012).

Second, evidence suggests that the impact of institutional environment on internationalisation outcomes can be mediated. For example, Zhang et al. (2017) find that international entrepreneurial capabilities can mediate between sub-national institutions and the performance of export-focused SMEs. Their arguments echo those of Jones et al. (2011), who noted in their review of international entrepreneurship that the institutional context may shape the entrepreneurial capabilities of international entrepreneurs.

The institutional context may also influence networking (Danis and Kiss, 2008), and network ties can mediate between the institutional environment and international expansion. For 
instance, Narooz and Child (2017) found that institutional agencies can help SMEs to develop network ties and thus reduce the perceived risk of internationalisation. Another fairly recent study by Oparaocha (2015) revealed that institutional networks can have a positive impact on the internationalisation efforts of SMEs. Similarly, the study by Freeman, Edwards and Shroeder (2006) of rapidly internationalising SMEs identified networks as the means by which firms can overcome industry-driven constraints in an external environment. International business network ties can influence the impact of export experience on export market performance (Ogasavara, Boehe and Barin Cruz, 2016). Further, managers' perceptions of institutional forces may affect the extent to which they seek inter-firm relationships to facilitate internationalisation (Acedo and Casillas, 2007), suggesting that mediation occurs via networks. Network-level variables may thus act as mediators between institutional forces and a firm's growth (Webb, Kistruck, Ireland and Ketchen, 2010).

Together, the studies described above provide empirical grounds to posit that the impact of institutional environments on SME internationalisation outcomes could be mediated by capabilities and that business networks are linked to both the institutional environment and SME internationalisation outcomes. Thus, the present study proposes that the degree to which an SME can develop and manage its network relationships (i.e. the extent to which it has network competence) (Ritter et al., 2002) can mediate the relationship between a conducive institutional environment and successful internationalisation of SMEs:

- H3: The level of network competence positively mediates the relationship between institutional drivers and the international performance of SMEs.

o H3a: The level of relationship-specific network competence positively mediates the relationship between institutional drivers and the international performance of SMEs. 
o H3b: The level of cross-relational network competence positively mediates the relationship between institutional drivers and the international performance of SMEs.

\section{Research Method}

\section{Data Collection}

The empirical data used to test the hypotheses were collected from a sample of 119 Finnish SMEs employing between 10 and 500 people from five industry sectors: food, furniture, metal, software and knowledge-intensive business services. The study setting is relevant for two main reasons. First, it is an empirical context within a developed economy, which has received far less attention in institutional theory research than emerging market contexts. There are some studies indicating that the institutional environment in Finland has a notable impact on corporate governance (Sinani, Stafsudd, Thomsen, Edling and Randøy, 2008) and international human resource management practices (Björkman, Fey and Park, 2007). Thus, based on extant studies, it is reasonable to assume that applying institutional theory to the context of Finland is relevant. However, how doing so affects the international growth of SMEs must still be determined.

Second, existing studies on network-enabled SME internationalisation suggest that business networks (Bell, 1995; Coviello and Munro, 1997; Loane and Bell, 2006) and network competence (Torkkeli et al., 2012) are quite important for internationalising SMEs from small, open economies such as that of Finland (Holmlund and Kock, 1998; Kuivalainen, Sundqvist and Servais, 2007). However, there are few, if any, studies on the relationship between institutional drivers and the barriers experienced by these types of firms and their 
business networks. Obtaining data from this context is intended to provide insight into these dynamics.

The data were collected over six months through an online web survey. A sample of SMEs from the Amadeus online database was drawn using the Organisation for Economic Cooperation and Development's (OECD's) definition of SMEs (i.e. firms with 10-500 employees) (OECD, 2008). The search was restricted to five industry sectors: metal, furniture, food, software and knowledge-intensive business services. These sectors were selected for the intensity of their knowledge or research and development. Our aim was to control the effect of knowledge intensity on internationalisation. Through the inclusion of both traditional manufacturing industries (SMEs from the metal, food and furniture industries) and more service-oriented knowledge-intensive fields (SMEs from the software and knowledgeintensive business service sectors), we sought to generalise the results. The selected industry sectors also facilitated comparison of SMEs from relatively traditional, low-technology manufacturing sectors and those from high-technology, more service-oriented sectors.

A two-part survey was developed using the Webropol online questionnaire tool. The first part of the survey was presented to all firms, while the second part was administered to only SMEs with international operations. The latter part included items concerning international activities, including the institutional barriers and drivers that affected the internationalisation of SMEs, the scale and scope of foreign operations and SMEs' subjective assessments of their international success. Some of the items in the questionnaire were negatively worded to avoid agreement bias and account for potentially extreme response styles (see Baumgartner and Steenkamp, 2001). Finally, the survey was back-translated with the help of a professional translator and piloted with managers from two different fields. 
In total, 1147 firms were identified from the database and subsequently contacted by phone and asked to participate in the survey. During the phone call, the researchers identified appropriate respondents within the company. These respondents received an e-mail with a link to the online survey. A printed questionnaire was offered as an alternative, but it was not requested by any of the respondents. Three rounds of reminder e-mails were sent to nonrespondents at two-week intervals. The response rate varied between the industry sectors. The metal industry had the lowest response rate $(16 \%)$, while the furniture industry had the highest (31\%). The respondents were roughly equally distributed between domestic (179, $60 \%)$ and international $(119,40 \%)$ respondents.

A total of 298 responses were received, resulting in a response rate of $26 \%$. Of these, 119 SMEs had international operations and thus were included in the final sample. Achieving higher response rates has been a challenge not only in Finland (e.g. Autio, Sapienza and Almeida, 2000) but also in research employing mail surveys in a smaller entrepreneurship context (Bartholomew and Smith, 2006; Newby, Watson and Woodliff, 2003). Interestingly, Rutherford, O’BoyleMiao, Goering and Coombs (2017, p. 93) found 'virtually no evidence that response rate has any meaningful or consistent influence on relationships in entrepreneurship, and...there is little evidence of selective reporting when response rates are low'. Therefore, we sought to ensure the validity and reliability of the current study by testing for possible biases beyond the overall response rate.

The SMEs had an average of 39 employees and an average turnover of 5.6 million euros. The respondents were mostly managing directors (191), owners (59) or other key persons in the organisation (40). Checking the job titles of key persons on the companies' websites and 
documentation revealed that most were managers from high-level strategic management and budgeting teams (e.g. CFOs, customer development managers and business development managers). ANOVA tests were conducted to ensure that the responses in the employed variables were not influenced by the type of respondent or the timing of the response and account for non-response bias. As none of the results of the tests were statistically significant, the sample was considered to be free of any bias related to the type of respondent or timing of the response.

In order to minimise the potential for common method bias, several steps were taken before and after data collection, in line with the recommendations of Podsakoff, MacKenzie, Lee and Podsakoff (2003) and Chang, Van Witteloostuijn and Eden (2010). First, the focal items were placed in different parts of the overall questionnaire and negatively worded items were included to minimise any halo effects. Second, the focal measures were made to seem like a part of a larger survey covering a range of issues for SMEs beyond internationalisation. As Chang et al. (2010, p. 179) noted, 'respondents are unlikely to be guided by a cognitive map that includes difficult-to-visualize interaction and non-visual effects'. As the hypotheses in this study aim to establish mediation relationships between constructs from different theoretical foundations (i.e. institutional theory and dynamic capabilities), it was unlikely that the respondents would have been guided by the hypothesised relationships. Third, Harman's single-factor test was conducted as an additional post-hoc test against potential common method bias. The results indicated that there were no single factors underlying the data that could have been a concern in the empirical analysis. Fourth, by including an objective performance indicator of the degree of internationalisation consisting of the total turnover and the number of countries in which the company operates, the researchers were able to adhere to the guidelines proposed by Podsakoff et al. (2003) and include a dependent variable from a 
different source than that from which the independent variables were obtained (cf. Chang et al., 2010, p. 178).

Fifth, Podsakoff, MacKenzie and Podsakoff (2012) have noted that it can be difficult to find a suitable instrument variable to control for common method variance. The marker variable technique is more suitable and was used to check for common method bias (cf. Lindell and Whitney, 2001). The number of domestic partners was regarded as a theoretically irrelevant variable and therefore usable as a marker variable. The marker variable had non significant correlations $(\mathrm{p}>0.10)$ with the theoretically relevant predictors and criterion variables. There were no major changes in magnitude or significance of the correlations between the independent and dependent variables when controlling for the marker variable in partial correlation analysis. Thus, common method bias was expected to not have an effect on the results of the study.

\section{Measure Development}

The measures for institutional forces were adapted based on earlier research on the institutional drivers of and barriers to internationalisation (Leonidou, 1995; 2000) within the institutional environment (Scott, 2001). Respondents were asked to report their perceptions of how the institutional drivers and barriers in their environment had affected their internationalisation process using a seven-point Likert scale. This study employed subjective measures since objective institutional measures are better for country-level analysis and subjective measures are more suitable for firm-level analysis. This is particularly true in the SME context, in which companies may or may not have specific departments or strategic business units, the entrepreneur's perceptions may have a large influence on the overall 
strategy of the company and the institutional forces perceived by individuals in power are likely to have a major effect on the internationalisation process.

Initially, 12 items were included in the measure. A two-factor solution was sought to distinguish between institutional drivers and barriers. By applying principal component analysis with the varimax rotation method and dropping items with insufficient commonality and factor loadings, a two-factor solution explaining $60 \%$ of the total variance was achieved. The Kaiser-Meyer-Olkin test of sampling adequacy showed that this solution had a value of 0.59. As the KMO value was borderline, the suitability of the data was ensured by observing the measure of sampling adequacy (MSA) values, expected to be $>0.50$. The range of observed values was 0.54-0.66, indicating adequate data. In addition, Bartlett's test of sphericity was statistically significant $(\mathrm{p}<0.01)$, indicating that the basic assumptions in the factor analysis model were fulfilled. The Cronbach's alpha values were 0.69 for institutional barriers and 0.61 for institutional drivers. The items' wording, descriptive statistics and factor loadings are shown in Table 1.

\section{(Table 1)}

The measure of network competence was based on the NetComp scale (Ritter et al., 2002) and was taken from an earlier study that examined the influence of network competence on SMEs' internationalisation (Torkkeli et al., 2012). Since the measure used in the present study was a shortened version of the NetComp scale, confirmatory factor analysis (CFA) was performed using Lisrel software. It indicated sufficient model fit for a two-dimensional network competence construct based on the relationship-specific and cross-relational scales outlined originally by Ritter et al. (2002). The RMSEA value was deemed acceptable (0.068), 
and the main fit indices were all above the 0.90 threshold $(\mathrm{GFI}=0.91, \mathrm{CFI}=0.95, \mathrm{NFI}=$ 0.91). The normed chi-square was 2.12 . The convergent validity of the scales was determined by estimating the average variance extracted (AVE) and composite reliability (e.g. Diamantopoulos and Siguaw, 2000). Testing for discriminant validity was conducted following the heterotrait-monotrait ratio of correlations (HTMT) method (Henseler, Ringle and Sarstedt, 2015). The values for this test were 0.36 for the institutional (drivers and barriers) measures and 0.85 for the network competence (cross-relational and relationshipspecific) measures. Both of the values were below the 0.90 threshold recommended by Gold, Malhotra and Segars (2001) and Teo, Srivastava and Jian (2008). In addition, square roots of all average variance extracted (AVE) values were examined and found to be significantly higher in values than correlations among constructs, thus providing added support for the discriminant validity of the constructs (cf. Fornell and Larcker, 1981). In addition, two alternative models were run: one including all the items concerning network competence within the proposed dimensions and one with a one-factor model. The results of the CFA of network competence with the items listed in Appendix 1 outperformed the two alternative models by a significant margin.

International performance is one of the main outcomes assessed by quantitative research on international entrepreneurship (Knight, 2001). It has been explained through either an 'objective' measure termed the degree of internationalisation (cf. Sullivan, 1994) or subjective assessment of how well an SME succeeded in reaching its internationalisation goals. However, in general, international performance should be measured by multidimensional measures (Katsikeas, Samiee and Theodosiou, 2006; Zou and Stan, 1998). To account for potential common method bias, both subjective and objective measures of international performance were used in the analysis. Specifically, our objective measure of 
international performance captured the scale (foreign share of turnover) and scope (the number of countries in which the company operated) of international activities. The subjective performance measure was estimated by a set of items on a Likert scale, which converged on a single-measure scale with a Cronbach's alpha value of 0.95 (see Appendix 1 for the individual items). To determine whether an objective or subjective performance measure should be emphasised for individual results, the two hypothesis-testing models were employed individually for each type of performance. They were then standardised and combined into one international performance measure, which captured the dimensions of scale, scope and strategic success.

Finally, we controlled for the firm's size (measured by the number of employees), industry sector and age. These control variables were chosen because, as pointed out in the literature review above, new, small, high-technology firms tend to benefit most (and be most dependent on) networks (e.g. Madsen and Servais, 1997; Coviello and Munro, 1997). For this reason, the industry sector variable was created to distinguish between high-tech sectors (software), lowtech sectors (food and furniture) and sectors with medium technological intensity (metal, knowledge-intensive business services). High-technology fields, such as the software industry, are also newer compared to, for instance, the metal and furniture industries. Thus, high-technology SMEs are expected to be of newer origin. Firm age could complicate the relationships between the institutional environment, networks and internationalisation outcomes. In addition, older and larger firms likely had more time to develop capabilities (cf. Sapienza, Autio, George and Zahra, 2006) such as network competence, which must be controlled for. In general, the comparatively small size of SMEs means that they are constrained in terms of resources, which is part of the reason that network use is important in internationalisation. Therefore, firm size, age and industry sector were controlled for when 
testing the hypotheses. As there were only seven firms with 250-500 employees compared to 291 firms with 10-250 employees, the former seven were considered outliers in the data when running the analysis. The descriptive statistics and intercorrelations between the variables are presented in Table 2 .

(Table 2)

\section{Results}

Linear regression modelling was applied to test hypotheses H1 and H2. The controls-only model was run first, and then the relevant hypothesis variables were added to the second model. The results of the analysis are presented in Table 3. They support H1 (institutional drivers are positively related to international performance) but only very weakly support $\mathrm{H} 2$ (institutional barriers are negatively related to international performance). The controls-only model (Table 3, model 1) was not statistically significant $(F=1.72, p>0.05)$. Thus, the control variables did not significantly help explain the variance in international performance.

The results of the main model concerning both types of international performance (Table 3, models 2 and 3) and composite international performance (Table 3, model 4) confirmed that the perceived institutional drivers had a positive and significant relationship with objective international performance $(\beta=0.41, \mathrm{p}<0.01)$ and that the barriers had a negative and significant impact $(\beta=-0.26, \mathrm{p}>0.05)$. When testing subjective international performance, only the influence of the drivers $(\beta=0.38, \mathrm{p}<0.01)$ was statistically significant. The same was true for the total international performance measure $(\beta=0.39, \mathrm{p}<0.01)$. The models were also significant overall (objective: $\mathrm{F}=6.06, \mathrm{p}<0.01$; subjective: $\mathrm{F}=2.45, \mathrm{p}<0.05$; 
total $\mathrm{F}=2.67, \mathrm{p}>0.01$ ), and the adjusted $\mathrm{R}^{2}$ indicated that the explanatory power of the total international performance measure (Table 3 , model 4) was approximately $18 \%$. Considering that the barriers coefficient was statistically significant for only one of the performance measures at a 0.05 level (rather than 0.01 , as for the drivers), the analysis did not provide strong evidence in favour of H1. Additionally, while the coefficient was negative and significant in one model (Table 3, model 2), it did not remain so for different types of international performance. Higher levels of institutional drivers were found to lead to increased international performance among SMEs across all measures, supporting H2.

\section{(Table 3)}

We checked for potential multicollinearity and heteroscedasticity problems with the results. The error residuals in the analysis were found to be normally distributed, indicating no issues with heteroscedasticity. Further, statistical tolerance and variance inflation factor scores were examined to detect possible multicollinearity between variables. However, as the former showed values between 0.3 and 1.0 and the values of the latter were between 1.0 and 3.0, no issues with multicollinearity were detected.

For $\mathrm{H} 3$, mediation analysis was conducted to establish whether network competence mediates the relationship between environmental drivers and internationalisation outcomes. The fourstep approach suggested by Baron and Kenny (1986) was followed to investigate the possible effects of mediation. Kenny (2008) argues that Sobel's test would be, to some extent, nonindependent when logistic regression, latent variable models and multi-level modelling are performed with the applied method, but 'when multiple regression is used, they are independent' (Kenny, 2008, p. 4). This is assumed when using Sobel's test. In this study, 
multiple regression modelling was used, and Sobel's test was deemed an adequate method of establishing mediation. However, it is acknowledged here that the discussion on mediation testing is under continuous discussion and there is no consensus regarding the best practices.

As the intercorrelations between variables (see Table 2) indicated a lack of requirements for establishing the mediating effects of environmental barriers for any of the performance measures, we focused on the possibility that network competence mediates the relationship between environmental drivers with total international performance. First, regression analyses were conducted to assess the components of mediation by examining the unstandardised raw coefficients. The relationship between institutional drivers and CRR was found to be significant $(\mathrm{B}=0.22, \mathrm{~F}=5.48, \mathrm{p}<0.05)$, as was the relationship between $\mathrm{CRR}$ and international performance $(\mathrm{B}=0.64, \mathrm{~F}=11.92, \mathrm{p}<0.01)$. Likewise, a direct effect was observed between environmental drivers and international performance $(\mathrm{B}=0.59, \mathrm{~F}=10.02$, $\mathrm{p}<0.01)$. As the requirements for Baron and Kenny's four-step process were satisfied, the Sobel values (Sobel, 1982) and probabilities for CRR were calculated. The results of Sobel's test $(1.93, \mathrm{p}<0.05)$ showed a positive mediation relationship, with CRR mediating the positive relationship between institutional drivers and international performance. A similar analysis was conducted with RSS, but the results of Sobel's test were non-significant (1.84, p $>0.05)$

In sum, our empirical results showed that the determinants of the international performance of SMEs may depend on the perceived institutional drivers of SMEs rather than the perceived barriers. Institutional drivers also had an indirect effect on international performance mediated by CRR. Next, the implications of these results along with the study limitations and directions for further research are discussed. 


\section{Discussion}

The results highlight several points that require discussion. First, institutional drivers seem to be highly important for SMEs' foreign market expansion. This supports the findings of Yang, Jiang and Kang (2009) concerning firms' first entry into foreign markets. The results also suggest that, beyond the first entry into foreign markets, network competence is relevant for SMEs as they seek to extend their international operations beyond the initial stage. Specifically, the ability to manage the network level (CRR), rather than the ability to maximise individual alliances (RSS), plays an important role in the extension of international operations. Our results align with studies that have linked successful business networking to successful internationalisation among SMEs from small, open economies (Bell, 1995; Coviello and Munro, 1995; 1997; Madsen and Servais, 1997; Loane and Bell, 2006; Sasi and Arenius, 2008; Torkkeli et al., 2012) and studies that have conceptualised network-related dynamic capabilities (Mitrega et al., 2012; Mort and Weerawardena, 2006). In addition, they help extend the recent discussion in literature on international entrepreneurship and marketing that has emphasized the role of institutions (Oyedele and Firat, 2018) as well as on the importance of networks and network ties (e.g., Chen et al., 2018; Nyuur et al., 2018; Yamin and Kurt, 2018) by linking the two types of studies together through mediation effects.

It is suggested that the predictable path dependence of the institutional environment may give SMEs the opportunity to develop their network competence over time, thus enabling improved performance. The mediation effect found in our analysis seems to confirm this notion; when the perceived institutional drivers were high, the firms were able to perform well in international markets. Further, the drivers led to increased network competence, which 
was a significant determinant of international performance. This clarifies the results of extant studies indicating a connection between networks and institutional forces (Bell and Cooper, 2018; Danis and Kiss, 2008; Ferreira, Li and Suk, 2009; Webb et al., 2010); our results suggest that prevalent drivers of internationalisation may encourage SMEs to develop the network-related capabilities they need for global competition.

\section{Conclusion}

The point of departure in this study was the research question: What is the relationship between the perceived institutional environment and network capabilities in successful internationalisation of SMEs? Based on the empirical analysis, the main conclusion is that network capabilities, captured in this study by the construct of network competence, can mediate between favourable institutional environments for SMEs and successful internationalisation outcomes. The theoretical contribution and managerial implications of this result are considered below.

\section{Theoretical Implications}

This study contributes to literature on international entrepreneurship in several ways. First, it adds to the understanding of the external environment, which is important for understanding international entrepreneurial behaviour (Szyliowics and Galvin, 2010). Research applying institutional theory to international business, international marketing and entrepreneurship has tended to focus mainly on emerging economies (cf. Ahlstrom and Bruton, 2006; Peng, Wang and Jiang, 2008; Meyer, Estrin, Bhaumik and Peng, 2009). A developed market - that of Finland - was chosen for this study because such markets are less examined. 
Second, the study contributes to literature applying institutional theory to international business and entrepreneurship, finding that, in addition to international entrepreneurial capabilities (Zhang et al., 2017), network capabilities can mediate the relationship between institutional forces and increasingly successful entrepreneurial internationalisation. In doing so, the study also extends the literature on network-driven entrepreneurial internationalisation in general (e.g., Coviello and Munro 1995; 1997; Loane and Bell, 2006) and on the impact of institutions on networking behaviour in particular (Eriksson et al., 2017; Narooz and Child, 2017). It suggests that both can be explained, to an extent, with the dynamic capability view. The unique contribution of this study is its outline of how network-related dynamic capabilities can help explain the relationship between institutional environment and international performance.

Third, as Szyliowicz and Galvin (2010) noted in their review, the majority of scholars applying institutional theory to IE have used a case study approach. By examining the institutional environment with a survey-based study, we add to the literature by using a less common methodology. In addition, the research concerning the institutional environment in international entrepreneurship has tended to concentrate on a specific industry or sector (Szyliowicz and Galvin, 2010). The present study, in contrast, applied a cross-sectional sample of firms from different industry sectors.

Fourth, by examining the dynamics of external (institutional environment) and internal (network competence) forces, this study contributes to the literature on SME internationalisation by accounting for both types of determinants. This is also one of the few studies that incorporates both institutional theory and the dynamic capabilities view to examine the determinants of success in internationalising SMEs. This study therefore 
contributes to the discussion on the determinants of internationalisation and international success among SMEs and to the understanding of the interplay between institutional forces and internal organisational competences in the internationalisation of firms.

Fifth, this study answers earlier studies' (such as Acedo and Casillas, 2007; Danis and Kiss, 2008; Jones et al., 2011) call to examine aspects of networks and institutions in parallel when exploring the determinants of successful internationalisation. In addition, this study indicates that, by developing network-related dynamic capabilities, SMEs can truly leverage a favourable institutional environment to international success. The review of SME internationalisation literature by Ruzzier, Hirsich and Antoncic (2006) notes that earlier research on international entrepreneurship tended to neglect the dynamic capability view (Eisenhardt and Martin, 2000; Teece et al., 1997), and its impact on internationalising enterprises is still not well understood (Peiris, Akoorie and Sinha, 2012). The role of networkrelated capabilities in this context is relevant, as firms' environment tends to influence how well they are able to leverage their dynamic capabilities (Zahra, Sapienza and Davidsson, 2006). This study has provided some empirical evidence for this connection and outlined another context in which dynamic capabilities are relevant to international entrepreneurship.

\section{Managerial Implications}

The results have some managerial implications. First, institutional barriers do not seem to hinder Finnish SMEs from operating internationally, growing and achieving their strategic goals for internationalisation. However, the generalisability of the results is limited since the perceived institutional barriers, and thus their influence on internationalisation, may be higher or lower depending on the context of the country in question. 
The results further suggest that, to successfully pursue their international strategies, SMEs should take the institutional environment into account. However, for successful internationalisation, they should also develop network competence (i.e. the ability to develop and manage their business networks). Thus, one of the key implications of this work is that dynamic capabilities are temporally important in the Finnish setting, where it is beneficial to build network competence as a strategic move to achieve international growth.

The results also suggest that practitioners should aim to favour network-level capabilities in planning, organizing, controlling and staffing their business network relationships. Conversely, relationship-specific capabilities may not be similarly useful in enabling SME managers make full use of the home country institutional drivers for internationalisation: As the relationship-specific network competence consists of initiation, coordination and exchange activities, the implications are that visiting networking events and trade fairs may not be enough to make use of an institutional environment favourable to internationalisation. Similarly, simply being able to engage in confidential exchange of information in one's business relationships may in itself also not be enough for managers of SMEs to successfully internationalise their enterprises.

For political decision-makers this also implies that networking events and trade fairs may not be the best use of public money when the aim is to support growth entrepreneurship and international growth of local SMEs. Finally, public actors should note that an institutionally conducive environment that drives domestic SMEs toward international markets may be an antecedent to firms' development of the capabilities they need to succeed abroad.

\section{Limitations and Further Research}


Naturally, the results of this study have some limitations and open opportunities for future research. One limitation is that, because of the cross-sectional nature of the data, the strength of the causality between international performance and institutional perception that can be derived from the empirical analysis is limited. It may be possible that more internationalised SMEs may develop perceptions of their domestic institutional environment over time due to their growing international experience. This can be further explained by future studies with the help of a longitudinal study setting.

The possibility that SMEs may develop their dynamic capabilities, such as network competence, as a result of the institutional environment can also be investigated. Another limitation of this study is the fact that the institutional drivers and barriers were only examined from the point of view of internationally operating SMEs. Thus, any comparison between domestically and internationally operating enterprises (e.g. the propensity for an SME to internationalise) is outside the scope of this research. Comparative cross-country research could provide valuable insights in this context by examining whether the dynamics of capability development are different in home countries with high institutional barriers. In particular, the impact of institutions and networks on the internationalisation of entrepreneurial firms may be due to different dynamics in emerging markets (e.g. He, 2012; Kiss and Danis, 2010; Shirokova and McDougall-Covin, 2012). Future research could investigate whether these differences have an influence on the capability development process.

The single-country context is a potentially significant limitation to the generalisability of the results. Finland, a small and relatively homogenous country with a developed institutional structure for supporting SMEs, is a specific empirical context in which we outlined the impact 
of institutional forces on internationalisation. Future research could adopt a cross-national view to allow for comparison of this type of environment with one in which a more diverse set of institutional experiences is the norm.

This study also did not account for institutional dimensions outside the immediate sphere of neo-institutional theory, such as the conducive dimension (Stenholm et al., 2013). Future research could examine such dimensions in greater detail to obtain a holistic picture of institutional forces in the context of capability development and SME internationalisation. It could also explore the connection between business networks and institutional forces and apply a comprehensive scale separating the cognitive, regulatory and normative pillars (see Busenitz et al., 2000; Kostova, 1997; Manolova, Eunni and Gyoshev, 2008), as they have seldom been empirically tested at the industrial or firm level. In light of the comprehensive institutional profiles suggested by the studies above, the measures for institutional drivers and barriers could be considered rudimentary and exploratory, as they were chosen to capture institutional drivers and barriers to internationalisation. In this study, an adequate model for CFA of this measure could not be developed. Thus, analysis was constrained to exploratory factor analysis, which is another empirical limitation.

In sum, this study is a step toward applying institutional theory at the meso- and micro-levels of analysis, as recommended by Su et al. (2017). In the words of Szyliowicz and Galvin (2010, p. 328), '[u]nderstanding the role that institutions play in international entrepreneurship...is essential for theoretical development'. It can be argued that the same is true for international marketing literature, which could benefit from more knowledge on the impact of marketing capabilities as a potential mediator between institutional environments and international performance outcomes. 


\section{References}

Acedo, F. J. and Casillas, J. C. (2007), “Age at entry in international markets of Spanish

SMEs: Entrepreneurial and institutional determinants", International Journal of

Entrepreneurial Behaviour \& Research, Vol. 13 No. 3, pp. 130-150.

Agndal, H. and Chetty, S. (2007), “The impact of relationships on changes in internationalization strategies of SMEs”, European Journal of Marketing, Vol. 41 Nos. 11/12, pp. 1449-1474.

Ahlstrom, D. and Bruton, G. D. (2006), "Venture capital in emerging economies: Networks and institutional change", Entrepreneurship Theory and Practice, Vol. 30 No. 2, pp. 299-320.

Aspelund, A., Madsen, T.J. and Moen, O. (2007), “A review of the foundation, international marketing strategies, and performance of international new ventures", European Journal of Marketing, Vol. 41 Nos. 11/12, pp. 1423-1448.

Autio, E., Sapienza, H. J. and Almeida, J. G. (2000), "Effects of age at entry, knowledge intensity, and imitability on international growth", Academy of Management Journal, Vol. 43 No. 5, pp. 909-924.

Balabanis, G., Theodosiou, M. and Katsikeas, E.S. (2004), "Export marketing: developments and a research agenda", International Marketing Review, Vol. 21 Nos. 4/5, pp. 353-377. 
Baron, R.M. and Kenny, D.A. (1986), “The moderator-mediator variable distinction in social psychological research: Conceptual, strategic and statistical considerations", Journal of Personality and Social Psychology, Vol. 51 No. 6, pp. 1173-1182.

Bartholomew, S. and Smith, A. D. (2006), "Improving survey response rates from Chief Executive Officers in small firms: The importance of social networks", Entrepreneurship Theory \& Practice, Vol. 30 No. 1, pp. 83-96.

Baumgartner, H. and Steenkamp, J-B.E.M. (2001), "Response Styles in Marketing Research: A Cross-National Investigation”, Journal of Marketing Research, Vol. 38 No. 2, pp. 143-156.

Bell, J. (1995), “The internationalization of small computer software firms: A further challenge to "stage" theories", European Journal of Marketing, Vol. 29 No. 8, pp. 60-75.

Bell, V. A. and Cooper, S. Y. (2018), "Institutional knowledge: Acquisition, assimilation and exploitation in internationalisation”, International Marketing Review, Vol. 35 No. 3, pp. 475497.

Björkman, I., Fey, C. F. and Park, H. J. (2007), "Institutional theory and MNC subsidiary HRM practices: Evidence from a three-country study”, Journal of International Business Studies, Vol. 38 No. 3, pp. 430-446.

Brouthers, K.D. and Brouthers, L.E. (2001), "Explaining the National Cultural Distance Paradox”, Journal of International Business Studies, Vol. 32 No. 1, pp. 177-189. 
Brouthers, K.D. and Brouthers, L.E. (2002), “Institutional, Cultural and Transaction Cost Influence on Entry Mode Choice and Performance, Journal of International Business Studies, Vol. 33, No. 2, pp. 203-221.

Brouthers K.D. and Hennart, J.-F. (2007), "Boundaries of the Firm: insights from International Entry Mode Research”, Journal of Management, Vol. 33, pp. 395-425.

Bruton, G.D. and Ahlstrom, D. (2003), “An institutional view of China's venture capital industry: Explaining the differences between China and the West", Journal of Business Venturing, Vol. 18, pp. 233-259.

Bruton, G. D., Ahlstrom, D. and Li, H. L. (2010), "Institutional theory and entrepreneurship: where are we now and where do we need to move in the future?" Entrepreneurship Theory and Practice, Vol. 34 No. 3, pp. 421-440.

Busenitz, L.W., Gomez, C. and Spencer, J.W. (2000), "Country institutional profiles: unlocking entrepreneurial phenomena”, Academy of Management Journal, Vol. 43 No. 5, pp. 994-1003.

Casper, S. and Whitley, R. (2004), "Managing competences in entrepreneurial technology firms: A comparative institutional analysis of Germany, Sweden and the UK", Research Policy, Vol. 33, pp. 89-106.

Chakravarthy, B. (1997), “A new strategy framework for coping with turbulence”, Sloan Management Review, Vol. 38, pp. 69-82.

Chang, S. J., Van Witteloostuijn, A., and Eden, L. (2010). From the editors: Common method variance in international business research. Journal of International Business Studies, Vol. 41 No. 2, pp. 178-184. 
Chen, J., Saarenketo, S., and Puumalainen, K. (2018), "Home country institutions, social value orientation, and the internationalization of ventures", International Business Review, Vol, 27 No. 2, pp. 443-454.

Coviello, N.E. and Munro, H.J. (1995), "Growing the entrepreneurial firm: Networking for international market development”, European Journal of Marketing, Vol. 29 No. 7, pp. 49-61.

Coviello, N.E. and Munro, H.J. (1997), "Network relationships and the internationalisation process of small software firms", International Business Review, Vol. 6 No. 4, pp. 361-386.

D’Arcy, E. (2009), “The evolution of institutional arrangements to support the internationalisation of real estate involvements: Some evidence from Europe", Journal of European Real Estate Research, Vol. 2 No. 3, pp. 280-293.

Dickson, P.H. and Weaver, K.M. (2008), "The role of the institutional environment in determining firm orientations towards entrepreneurial behaviour”, International Entrepreneurship Management Journal, Vol. 4, pp. 467-480.

DiMaggio, P.J. (1988), “Interest and agency in institutional theory”, In: Institutional patterns and organizations: Culture and environment, Lynne G. Zucker, ed. Cambridge: Ballinger Pub. Co.: pp. 3-21.

DiMaggio, P.J. (1991), “Constructing an organizational field as a professional project: U.S. art museums, 1920-1940”, In: The new institutionalism in organizational analysis, Walter W. Powell and Paul J. DiMaggio, eds. Chicago: University of Chicago Press: pp. 267-292. 
Dimitratos, P., Amorós, J. E., Etchebarne, M. S. and Felzensztein, C. (2014), “Micromultinational or not? International entrepreneurship, networking and learning effects", Journal of Business Research, Vol. 67 No. 5, pp. 908-915.

Dimitratos, P., Johnson, J.E., Slow, J. and Young, S. (2003), “Micro-multinationals: New types of firms for the global competitive landscape”, European Management Journal, Vol. 21 No. 2, pp. 164-174.

Dow, D. and Larimo, J. (2009), "Challenging the Conceptualization and Measurement of Distance and International Experience in Entry Mode Choice Research", Journal of International Marketing, Vol. 17 No. 2, pp. 74-98.

Eisenhardt, K., and Martin, J. (2000), “Dynamic Capabilities: What Are They?”, Strategic Management Journal, Vol. 21, pp. 1105-1122.

Eriksson, K., Fjelstad, O. and Jonsson, S. (2017). Transaction services and SME internationalization: The effect of home and host country bank relationships on international investment and growth. International Business Review, Vol., 26, pp. 130-144.

Ferreira, M.P., Li, D. and Suk, J.Y. (2009), "Foreign entry strategies: Strategic adaptation to various facets of the institutional environment", Development and Society, Vol. 38 No. 1, pp. $27-55$ 
Freeman, S., Edwards R. and Schroder, B. (2006), "How Smaller Born-Global Firms Use Networks and Alliances to Overcome Constraints to Rapid Internationalization", Journal of International Marketing, Vol. 14 No. 3, pp. 33-63.

Gaba, V., Pan, Y. and Ungson, G.R. (2002), “Timing of entry in international market: An empirical study of U.S. Fortune 500 firms in China", Journal of International Business Studies, Vol. 33 No. 1, pp. 39-55.

García-Ramos, C., Gonzalez-Alvarez, N., and Nieto, M. (2017), "Institutional framework and entrepreneurial failure”, Journal of Small Business and Enterprise Development, Vol. 24, No. 4, pp. 716-732.

Gold, A. H., Malhotra, A. and Segars, A. H. (2001), "Knowledge management: An organizational capabilities perspective”, Journal of Management Information Systems, Vol. 18 No. 1, pp. $185-214$.

He, L., Gu, J., Wu, J and Lado, A.A. (2018) Regulatory focus, environmental turbulence, and entrepreneur improvisation. International Entrepreneurship and Management Journal, Vol. 13, pp. 129-148.

He, X. (2012), “Theory and practice of emerging market firm internationalization: perspectives from Chinese non-state-owned entrepreneurship ventures", Journal of International Business and Entrepreneurship Development, Vol. 6, No. 1, pp. 4-33. 
Henseler, J., Ringle, C. M. and Sarstedt, M. (2015), “A new criterion for assessing discriminant validity in variance-based structural equation modelling", Journal of the Academy of Marketing Science, Vol. 43 No. 1, pp. 115-135.

Hoffman, A.J. (1997), From Heresy to Dogma: An institutional history of corporate environmentalism. San Fransicisco: New Lengsington Press.

Hoffman, A. J. (1999), "Institutional evolution and change: Environmentalism and the US chemical industry”, Academy of Management Journal, Vol. 42, No. 4, pp. 351-371.

Holmlund, M., and Kock, S. (1998), "Relationships and the Internationalisation of Finnish Small and Medium-Sized Companies”, International Small Business Journal, Vol. 16, No. 4, pp. 46-63.

Hopp, C. and Stephan, U. (2012), "The influence of socio-cultural environments on the performance of nascent entrepreneurs: Community culture, motivation, self-efficacy and startup success", Entrepreneurship \& Regional Development, Vol. 24 Nos. 9-10, pp. 917-945.

Håkansson, H. (ed.). (1982), International marketing and purchasing of industrial goods. New York:Wiley.

Håkansson, H., and Snehota, I. (eds). (1995), Developing Relationships in Business Networks. Routledge:London.

Johanson, J. and Vahlne, J.-E. (1977), “Internationalization Process of Firm - Model of Knowledge Development and Increasing Foreign Market Commitments”, Journal of International Business Studies, Vol. 8, No. 1, pp. 23-32. 
Johanson, J. and Vahlne, J.-E. (2003), "Business relationship learning and commitment in the internationalization process", Journal of International Entrepreneurship, Vol. 1, No. 1, pp. 83-101.

Johanson, J. and Vahlne, J.-E. (2009), “The Uppsala internationalization process model revisited: from liability of foreignness to liability of outsidership", Journal of International Business Studies, Vol. 40, No. 9, pp. 1411-1431.

Johanson, J. and Mattsson, L.-G. (1988), "Internationalization in industrial systems - a network approach", In: Strategies in Global Competition, Neil Hood and Jan-Erik Vahlne, eds. New York: Croom Helm, pp. 214-287.

Jones, M.V. and Coviello, N.E. (2005), "Internationalization: conceptualising an entrepreneurial process of behavior in time", Journal of International Business Studies, Vol. 36 No. 3, pp. 284-303.

Jones, M.V., Coviello, N. and Tang, Y.K. (2011), "International Entrepreneurship research (1989-2009): A domain ontology and thematic analysis”, Journal of Business Venturing, Vol. 26 No. 6, pp. 632-659.

Jepperson, R.L. (1991), “Institutions, institutional effect, and institutionalism”, In: The new institutionalism in organizational analysis, W.W. Powell and P.J. DiMaggio, eds. Chicago: University of Chicago Press, pp.143-163. 
Kenny, D. A. (2008), "Reflections on mediation”, Organizational Research Methods, Vol. 11, No. 2, pp. 353-358.

Kalinic, I., Sarasvathy, S. D. and Forza, C. (2014), “Expect the unexpected': Implications of effectual logic on the internationalization process", International Business Review, Vol. 23 No. 3, pp. 635-647.

Katsikeas, C. S., Samiee, S., and Theodosiou, M. (2006), ”Strategy fit and performance consequences of international marketing standardization", Strategic Management Journal, Vol. 27, No. 9, pp. 867-890.

Khan, Z., and Lew, Y. K. (2018), "Post-entry survival of developing economy international new ventures: A dynamic capability perspective", International Business Review, Vol, 27, No. 1, pp. 149-160.

Kirca, A.H., Bearden, W.O. and Roth, K. (2011), "Implementation of market orientation in the subsidiaries of global companies: the role of institutional factors", Journal of the Academy of Marketing Science, Vol. 39, pp. 683-699.

Kiss, A. N., and Danis, W. M. (2008), “Country institutional context, social networks, and new venture internationalization speed", European Management Journal, Vol. 26, No. 6, pp. 388-399.

Kiss, A.N. and Danis, W.M. (2010), "Social networks and speed of new venture internationalization during institutional transition: A conceptual model”, Journal of International Entrepreneurship, Vol. 8, pp. 273-287. 
Kiss, A. N., Danis, W. M. and Cavusgil, S. T. (2012), "International entrepreneurship research in emerging economies: A critical review and research agenda”, Journal of Business Venturing, Vol. 27 No. 2, pp. 266-290.

Knight, G. (2000), "Entrepreneurship and marketing strategy: The SME under globalization”, Journal of International Marketing, Vol. 8 No. 2, pp. 12-32.

Kostova, T. (1997), "Country institutional profile: Concept and measurement”, Academy of Management Proceedings, Vol. 1, pp. 180-184.

Kostova, T. and Zaheer, S. (1999), “Organizational legitimacy under conditions of complexity: the case of the multinational enterprise", Academy of Management Review, Vol. 24, No. 1, pp. 64-81.

Kostova, T. and Roth, K. (2002), “Adoption of an organizational practice by subsidiaries of multinational corporations: institutional and relational effects", Academy of Management Journal, Vol. 45, No. 3, pp. 215-233.

Kostova, T., Roth, K. and Dacin, M.T. (2008), "Institutional Theory in the Study of Multinational Corporations: A Critique and New Directions", Academy of Management Review, Vol. 33, No. 4, pp. 994-1006.

Kuivalainen, O., Sundqvist, S. and Servais, P. (2007), "Firms Degree of Born-globalness, International Entrepreneurial Orientation and Export Performance", Journal of World Business, Vol. 42, pp. 253-267. 
Leonidou, L.C. (1995), “Export stimulation research: Review, Evaluation and Integration”, International Business Review, Vol. 4, No. 2, pp. 133-156.

Leonidou, L.C. (2000), “Barriers to export management: an organizational and internationalization analysis", Journal of International Management, Vol. 6, pp. 121-148.

Lim, D.S.K., Morse, E.A., Mitchell, R.K. and Seawright, K.K. (2010), "Institutional environment and entrepreneurial cognitions: A Comparative Business Systems Perspective”, Entrepreneurship theory and practice, Vol. 34, No. 3, pp. 491-516.

Lindell, M.K. and Whitney, D.J. (2001), “Accounting for common method variance in cross sectional research designs", Journal of Applied Psychology, Vol. 86 No. 1, pp. 114121

Loane, S. and Bell, J. (2006), "Rapid internationalization among entrepreneurial firms in Australia, Canada, Ireland and New Zealand: An extension to the network approach", International Marketing Review, Vol. 23, No. 5, pp. 467-485.

Madsen, T.K. and Servais, P. (1997), “The internationalization of born globals: an evolutionary process?", International Business Review, Vol. 6, No. 6, pp. 561-583. 
Manolova, T.S., Eunni, R.V. and Gyoshev, B.S. (2008), "Institutional environments for entrepreneurship: evidence from emerging economies in Eastern Europe”, Entrepreneurship Theory \& Practice, Vol. 32, No. 1, pp. 203-218.

Melo Brito, C. (2001), "Towards an institutional theory of the dynamics of industrial networks", Journal of Business \& Industrial Marketing, Vol. 16, No. 3, pp. 150-166.

Meyer, J.W. and Rowan, B. (1991), "Institutionalized organization: Formal structure as myth and ceremony", In: The new institutionalism in organizational analysis, Walter W. Powell and Paul J. DiMaggio, eds. Chicago: University of Chicago Press, pp. 41-62.

Meyer, K. E., Estrin, S., Bhaumik, S. K., and Peng, M. W. (2009), “Institutions, resources, and entry strategies in emerging economies”, Strategic Management Journal, Vol. 30 No. 1, pp. 61-80.

Minnitti, M. (2008), “The role of government policy on entrepreneurial activity: productive, unproductive, or destructive?", Entrepreneurship Theory and Practice, Vol. 32 No. 5, pp. 779-790.

Mitrega, M., Forkmann, S., Ramos, C. and Henneberg, S.C. (2012), "Networking capability in business relationships: Concept and scale development”, Industrial Marketing Management, Vol. 41, pp. 739-751.

Morgan, N. A., Feng, H. and Whitler, K. A. (2018), "Marketing Capabilities in International Marketing”, Journal of International Marketing, Vol. 26 No. 1, pp. 61-95. 
Mort, G.S. and Weerawardena, J. (2006), "Networking Capability and International Entrepreneurship: How Networks Function in Australian Born Global Firms", International Marketing Review, Vol. 23, No. 5, pp. 549-572.

Muralidharan, E., and Pathak, S. (2017), "Informal institutions and international entrepreneurship", International Business Review, Vol. 26, No. 2, pp. 288-302.

Narooz, R., and Child, J. (2017), "Networking responses to different levels of institutional void: A comparison of internationalizing SMEs in Egypt and the UK”, International Business Review, Vol. 26, No. 4, pp. 683-696.

Nasra, R. and Dacin, M.T. (2010), "Institutional Arrangements and International Entrepreneurship: The State as Institutional Entrepreneur" Entrepreneurship Theory and Practice, Vol. 34, No. 3, pp. 583-609.

Nath, P., Nachiappan, S. and Ramanathan, R. (2010), “The impact of marketing capability, operations capability and diversification strategy on performance: A resource-based view", Industrial Marketing Management, Vol. 39 No. 2, pp. 317-329.

Newby, R., Watson, J., and Woodliff, D. (2003), "SME survey methodology: Response rates, data quality, and cost effectiveness", Entrepreneurship Theory and Practice, Vol. 28 No. 2, pp 163-172. 
North, D.C. (1990), Institutions, institutional change and economic performance. New York: Cambridge University Press.

Nyuur, R. B., Brecic, R., and Debrah, Y. A. (2018), "SME international innovation and strategic adaptiveness: The role of domestic network density, centrality and informality", International Marketing Review, Vol, 35 No. 2, pp. 280-300.

OECD. (2008), Definition of small and medium sized enterprises (SMEs).

Ogasavara, M. H., Boehe, D. M., and Barin Cruz, L. (2016), "Experience, resources and export market performance: The pivotal role of international business network ties", International Marketing Review, Vol. 33 No. 6, pp. 867-893.

Oparaocha, G. O. (2015). SMEs and international entrepreneurship: An institutional network perspective. International Business Review, 24(5), 861-873.

Oyedele, A., and Firat, F. (2018), “Institutional interactions and foreign firms' strategies under tribal rule complexities in emerging markets", International Marketing Review, Vol. 35, No. 2, pp. 236-257.

Oviatt, B.M. and McDougall, P.P. (1994), “Toward a theory of international new ventures”, Journal of International Business Studies, Vol. 25 No. 1, pp. 45-64. 
Oviatt, B.M., and McDougall, P.P. (2005), "Defining international entrepreneurship and modeling the speed of internationalization”, Entrepreneurship Theory and Practice, Vol. 29 No. 5, pp. 537-554.

Peiris, I. K., Akoorie, M. E. and Sinha, P. (2012), “International entrepreneurship: A critical analysis of studies in the past two decades and future directions for research", Journal of International Entrepreneurship, Vol. 10 No. 4, pp. 279-324.

Peng, M.W. (2003), "Institutional transitions and strategic choices", Academy of Management Review, Vol. 28 No. 2, pp. 275-296.

Peng, M. W., Wang, D. Y., and Jiang, Y. (2008), “An institution-based view of international business strategy: A focus on emerging economies”, Journal of International Business Studies, Vol. 39 No. 5, pp. 920-936.

Phillips, N., Tracey, P. and Karra, N. (2009), "Rethinking institutional distance: strengthening the tie between new institutional theory and international management", Strategic Organization, Vol. 7 No. 3, pp. 339-348.

Podsakoff, P. M., MacKenzie, S. B., Lee, J. Y. and Podsakoff, N. P. (2003), “Common method biases in behavioral research: A critical review of the literature and recommended remedies", Journal of applied psychology, Vol. 88, No. 5, 879-903

Podsakoff, P. M., MacKenzie, S. B. and Podsakoff, N. P. (2012), "Sources of method bias in social science research and recommendations on how to control it", Annual Review of Psychology, Vol. 63, pp. 539-569. 
Rajagopal, B. (2000), "From Resistance to Renewal: The Third World, Social Movements, and the Expansion of International Institutions”, Harvard International Law Journal, Vol. 41, No. 2, pp. 529.

Rennie, M.W. (1993), “Born global”, McKinsey Quarterly, Vol. 4, pp. 45-52.

Ritter, T. (1998), Innovationserfolg durch Netzwerk-Kompetenz: Effektives Management von Unternehmensnetzwerken. Wiesbaden: Gabler.

Ritter, T., Wilkinson, I.F. and Johnston, W.J. (2002), "Measuring network competence: some international evidence", Journal of Business \& Industrial Marketing, Vol. 17, pp. 119-138.

Rutherford, M. W., O’Boyle, E. H., Miao, C., Goering, D., and Coombs, J. E. (2017), "Do response rates matter in entrepreneurship research?", Journal of Business Venturing Insights, Vol. 8, pp. 93-98.

Ruzzier, M., Hisrich, R. D. and Antoncic, B. (2006), "SME internationalization research: past, present, and future”, Journal of Small Business and Enterprise Development, Vol. 13 No. 4, pp. 476-497.

Sambharya, R., \& Musteen, M. (2014), "Institutional environment and entrepreneurship: An empirical study across countries”, Journal of International Entrepreneurship, Vol. 12 No. 4, pp. 314-330. 
Sapienza, H. J., Autio, E., George, G., and Zahra, S. A. (2006), “A capabilities perspective on the effects of early internationalization on firm survival and growth" Academy of Management Review, Vol. 31 No. 4, pp. 914-933.

Sasi, V. and Arenius, P. (2008), "International new ventures and social networks: advantage or liability?” European Management Journal, Vol. 26 No. 6, pp. 400-411.

Scott, W. R. (1991), “Unpacking institutional arguments”, In: Powell, W. and DiMaggio, P (eds.). The new institutionalism in organizational analysis: Chicago: University of Chicago Press, pp. 164-182.

Scott, R.W. (1995), Institutions and Organizations. Thousand Oaks: Sage.

Scott, R.W. (2001), Institutions and Organizations. Thousand Oaks: Sage.

Sharma, D.D. and Blomstermo, A. (2003), "The internationalization process of born globals: A network view", International Business Review, Vol. 12, pp. 739-753.

Shenkar, O. (2001), "Cultural distance revisited: Towards a more rigorous conceptualization and measurement of cultural differences",. Journal of International Business Studies, Vol. 32 No. 3, pp. 519-535.

Shirokova, G. and McDourall-Covin, P. (2012), "The role of social networks and institutions in the internationalization of Russian entrepreneurial firms: Do they matter?", Journal of International Entrepreneurship, Vol. 10, pp. 177-199. 
Sinani, E., Stafsudd, A., Thomsen, S., Edling, C., and Randøy, T. (2008), “Corporate governance in Scandinavia: Comparing networks and formal institutions", European Management Review, Vol. 5 No. 1, pp. 27-40.

Sobel, M.E. (1982), “Asymptotic confidence intervals for indirect effects in structural equation models", In: Sociological Methodology 1982, S. Leinhardt (Ed.). Washington, DC: American Sociological Association.

Stenholm, P., Acs, Z.J. and Wuebker, R. (2013), "Exploring country-level institutional arrangements on the rate and type of the entrepreneurial activity", Journal of Business Venturing, Vol. 28 No.1, pp. 176-193.

Su, J., Zhai, Q. and Karlsson, T. (2017), "Beyond red tape and fools: Institutional theory in entrepreneurship research, 1992-2014", Entrepreneurship Theory and Practice, Vol. 41 No. 4, pp. 505-531.

Szyliowicz, D. and Galvin, T. (2010), “Applying broader strokes: Extending institutional perspectives and agendas for international entrepreneurship research", International Business Review, Vol. 19 No. 4, pp. 317-332.

Teece, D. J., Pisano, G. and Shuen, A. (1997), "Dynamic Capabilities and Strategic Management”, Strategic Management Journal, Vol. 18 No. 7, pp. 509-533.

Teo, T. S., Srivastava, S. C. and Jiang, L. (2008), ”Trust and electronic government success: An empirical study”, Journal of Management Information Systems, Vol. 25 No. 3, pp. 99-132. 
Thorelli, H. B. (1986), "Networks: between markets and hierarchies", Strategic Management Journal, Vol. 7 No. 1, pp. 37-51.

Torkkeli, L., Puumalainen, K., Saarenketo, S. and Kuivalainen, O. (2012), “The effect of network competence and environmental hostility on the internationalization of SMEs", Journal of International Entrepreneurship, Vol. 10 No. 1, pp. 25-49.

Urbano, D. and Alvarez, C. (2014), "Institutional dimensions and entrepreneurial activity: an international study", Small Business Economics, Vol. 42 No. 4, pp. 703-716.

Veciana, J.M. and Urbano, D. (2008), "The institutional approach to entrepreneurship research: Introduction", International Entrepreneurship and Management Journal, Vol. 4 No. 4, pp. 365-379.

Volchek, D., Jantunen, A. and Saarenketo, S. (2013), "The institutional environment for international entrepreneurship in Russia: Reflections on growth decisions and performance in SMEs”, Journal of International Entrepreneurship, Vol. 11 No. 4, pp. 320-350.

Webb, J.W., Ireland, R.D, Hitt, M.A., Kistruck, G.M. and Tihanyi, L. (2011), "Where is the opportunity without the customer? An integration of marketing activities, the entrepreneurship process, and institutional theory", Journal of the Academy of Marketing Science, Vol. 39 No. 4, pp. 537-554.

Webb, J.W., Kistruck, G.M., Ireland, R.D. and Ketchen, D.J.Jr. (2010), “The entrepreneurship process in base of the pyramid markets: the case of multinational enterprise/nongovernment organization alliances", Entrepreneurship Theory and Practice, Vol. 34 No. 3, pp. 555-581. 
Weerawardena, J., Mort, G. S., Liesch, P. W. and Knight, G. (2007), “Conceptualizing accelerated internationalization in the born global firm: A dynamic capabilities perspective", Journal of World Business, Vol. 42 No. 3, pp. 294-306.

Yamin, M. and Kurt, Y. (2018), "Revisiting the Uppsala internationalization model: Social network theory and overcoming the liability of outsidership", International Marketing Review, Vol, 35, No. 1, pp. 2-17.

Yang, Z., Su, C. and Fam, K. S. (2012), "Dealing with institutional distances in international marketing channels: Governance strategies that engender legitimacy and efficiency”, Journal of Marketing, Vol. 76 No. 3, pp. 41-55.

Yang, X., Jiang, Y. and Kang, R. (2009), “A comparative analysis of the internationalization of Chinese and Japanese firms”, Asia Pacific Journal of Management, Vol. 26 No. 1, pp. 141162.

Yiu, D. and Makino, S. (2002), “The Choice between Joint Venture and Wholly Owned Subsidiary: An Institutional Perspective”, Organization Science, Vol. 13 No. 6, pp. 667-683.

Zahra, S. A., Sapienza, H. J. and Davidsson, P. (2006), "Entrepreneurship and dynamic capabilities: a review, model and research agenda", Journal of Management Studies, Vol. 43 No. 4, pp. 917-955.

Zhang, M., Gao, Q. and Cho, H. S. (2017), “The effect of sub-national institutions and international entrepreneurial capability on international performance of export-focused SMEs: 
Evidence from China and South Korea", Journal of International Entrepreneurship, Vol. 15 No. 1, pp. 85-110.

Zou, S., and Stan, S. (1998), "The determinants of export performance: a review of the empirical literature between 1987 and 1997”, International Marketing Review, Vol. 15 No. 5, pp. 333-356. 
Table 1. The institutional factors, items, and descriptive statistics.

\begin{tabular}{|c|c|c|c|c|c|}
\hline Item & Mean & $\begin{array}{l}\text { Std. } \\
\text { dev. }\end{array}$ & $\begin{array}{l}\text { Item-to-total } \\
\text { correlation }\end{array}$ & $\begin{array}{c}\text { Alpha if } \\
\text { item } \\
\text { deleted }\end{array}$ & $\begin{array}{l}\text { Factor } \\
\text { loading }\end{array}$ \\
\hline \multicolumn{5}{|l|}{ Institutional Drivers $(\alpha=0.61)$} & \\
\hline $\begin{array}{l}\text { Our home markets didn't provide enough } \\
\text { customers }\end{array}$ & 4.40 & 2.00 & 0.40 & 0.53 & 0.72 \\
\hline $\begin{array}{l}\text { There was a positive attitude towards } \\
\text { internationalization in our operational } \\
\text { environment }\end{array}$ & 5.10 & 1.50 & 0.38 & 0.31 & 0.74 \\
\hline $\begin{array}{l}\text { Internationalization was taken for granted } \\
\text { among the firms in the industry }\end{array}$ & 4.25 & 1.79 & 0.33 & 0.35 & 0.78 \\
\hline \multicolumn{5}{|l|}{ Institutional Barriers $(\alpha=0.69)$} & \\
\hline $\begin{array}{l}\text { Our internationalization was restricted by } \\
\text { domestic legislation or other regulations }\end{array}$ & 2.29 & 1.47 & 0.48 & 0.62 & 0.78 \\
\hline $\begin{array}{l}\text { Our internationalization was restricted by } \\
\text { the strongly negative domestic attitude } \\
\text { towards international business activities }\end{array}$ & 2.13 & 1.39 & 0.60 & 0.47 & 0.86 \\
\hline $\begin{array}{c}\text { Professional standards restricted our } \\
\text { internationalization }\end{array}$ & 2.55 & 1.55 & 0.44 & 0.68 & 0.71 \\
\hline
\end{tabular}


Table 2. The descriptive statistics and inter-correlations of the variables.

\begin{tabular}{|c|c|c|c|c|c|c|c|c|c|c|}
\hline Variables & 1 & 2 & 3 & 4 & 5 & 6 & 7 & 8 & 9 & \\
\hline $\begin{array}{c}1 . \\
\text { Environmental } \\
\text { drivers }\end{array}$ & 1 & & & & & & & & & \\
\hline $\begin{array}{c}2 . \\
\text { Environmental } \\
\text { barriers }\end{array}$ & 0.04 & 1 & & & & & & & & \\
\hline $\begin{array}{c}\text { 3. CRR } \\
\text { network } \\
\text { competence }\end{array}$ & $0.21 *$ & 0.15 & 1 & & & & & & & \\
\hline $\begin{array}{c}\text { 4. RSS } \\
\text { network } \\
\text { competence }\end{array}$ & $0.23 *$ & -0.03 & $0.82 * *$ & 1 & & & & & & \\
\hline $\begin{array}{l}\text { 5. Objective } \\
\text { international } \\
\text { performance }\end{array}$ & $0.37 * *$ & -0.21 & 0.04 & 0.01 & 1 & & & & & \\
\hline $\begin{array}{l}\text { 6. Subjective } \\
\text { International } \\
\text { Performance }\end{array}$ & $0.40 * *$ & -0.01 & $0.35 * *$ & $0.29 * *$ & $0.31 * *$ & 1 & & & & \\
\hline $\begin{array}{l}\text { 7. Firm age } \\
\text { (years) }\end{array}$ & 0.01 & 0.16 & -0.05 & 0.02 & 0.18 & 0.07 & 1 & & & \\
\hline $\begin{array}{l}\text { 8. Industry }(0 \\
=\text { low-tech, } 1 \\
=\text { medium, } 2= \\
\text { high-tech })\end{array}$ & 0.16 & -0.16 & $0.14 * *$ & 0.10 & 0.05 & 0.11 & $-0.43 * *$ & 1 & & \\
\hline $\begin{array}{l}\text { 9. Firm size } \\
\text { (employees) }\end{array}$ & -0.07 & -0.02 & -0.01 & 0.00 & 0.03 & 0.04 & $0.34 * *$ & $-0.13 *$ & 1 & \\
\hline $\begin{array}{c}10 . \\
\text { International } \\
\text { performance }\end{array}$ & $0.32 * *$ & -0.16 & $0.45 * *$ & $0.32 * *$ & $0.74 * * *$ & $0.81 * * *$ & -0.22 & 0.03 & 0.11 & 1 \\
\hline Mean & 4.55 & 2.26 & 4.16 & 4.47 & -0.01 & 4.33 & 27.07 & 1.92 & 33.12 & 0.27 \\
\hline Std. dev. & 1.35 & 1.15 & 1.30 & 1.41 & 1.58 & 1.71 & 21.30 & 0.78 & 38.26 & 1.48 \\
\hline
\end{tabular}


Table 3. The results of the linear regression analysis testing for international performance.

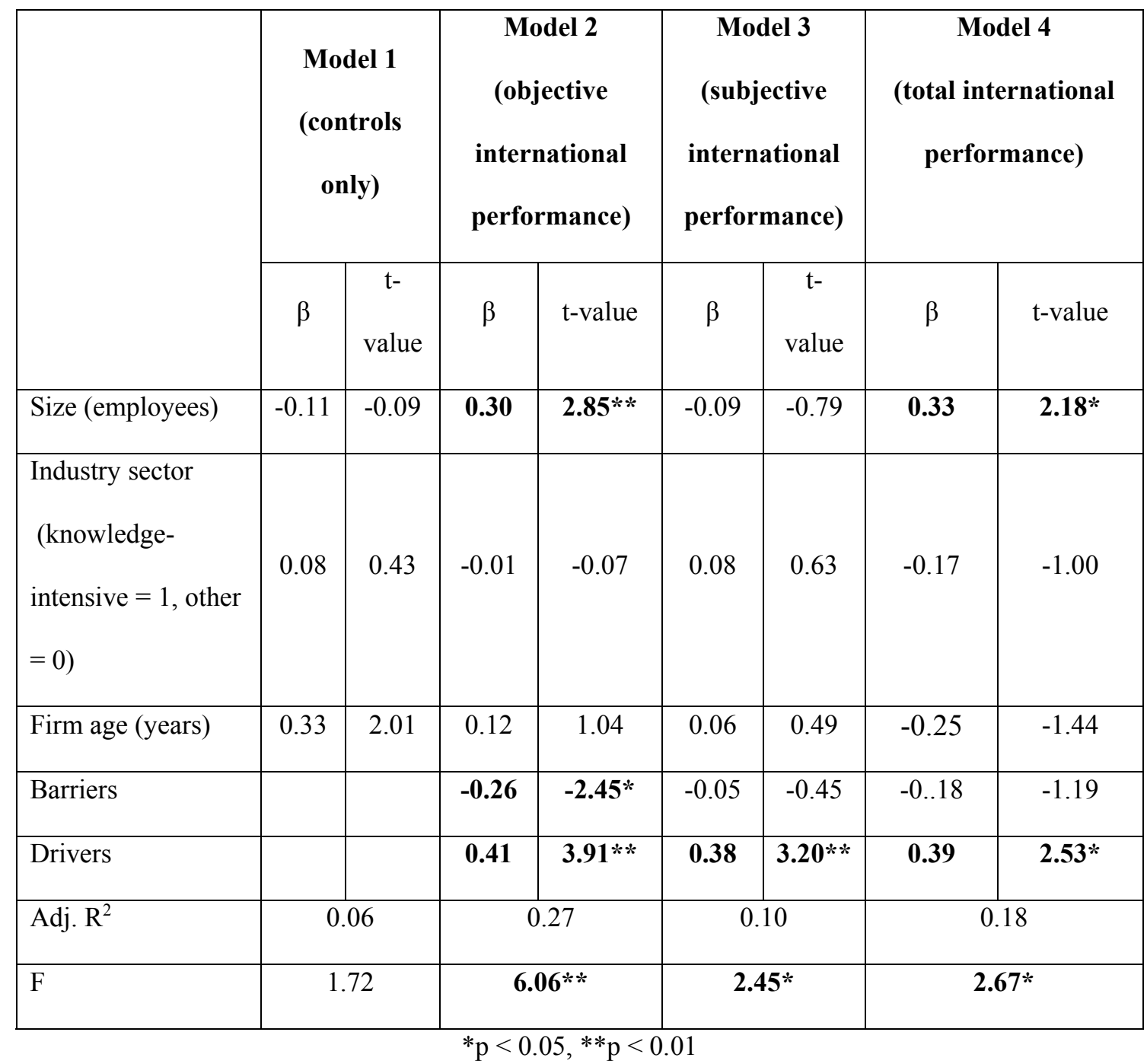

